Int. J. Dev. Biol. 56: 737-746 (2012)

doi: 10.1387/ijdb.120076hl

\title{
Restoring physiological cell heterogeneity in the mesenchyme during tooth engineering
}

\author{
LAETITIA-VÉRONIQUE KELLER ${ }^{1,2}$, SABINE KUCHLER-BOPP ${ }^{1,2}$ and HERVÉ LESOT ${ }^{*}, 1,2$ \\ ${ }^{1}$ INSERM UMR977 Biomatériaux et ingénierie Tissulaire, Strasbourg, France and \\ ${ }^{2}$ Faculté de Chirurgie Dentaire, Université de Strasbourg, France
}

\begin{abstract}
Tooth development is controlled by reciprocal epithelial-mesenchymal interactions. Complete teeth can form when culturing and implanting re-associations between single embryonic dental epithelial and mesenchymal cells. Although epithelial histogenesis is clear, very little is known about cell diversity and patterning in the mesenchyme. The aim of this work was to compare the situation in engineered and developing teeth at similar developmental stages. To this end, the expression of cell surface markers in the mesenchyme was investigated by immunostaining in: 1) embryonic mouse molars at embryonic day 14, as the initial cell source for re-associations, 2) cultured cell re-associations just before their implantation and 3) cultured cell re-associations implanted for two weeks. Surface markers allowed visualization of the complex patterning of different cell types and the differential timing in their appearance. The phenotype of mesenchymal cells rapidly changed when they were grown as a monolayer, even without passage. This might explain the rapid loss of their potential to sustain tooth formation after re-association. Except for markers associated with vascularization, which is not maintained in vitro, the staining pattern in the mesenchyme of cultured re-associations was similar to that observed in situ. After implantation, vascularization and the cellular heterogeneity in the mesenchyme were similar to what was observed in developing molars. Besides tissue oxygenation and its role in mineralization of dental matrices, vascularization is involved in the progressive increase in mesenchymal cell heterogeneity, by allowing external cells to enter the mesenchyme.
\end{abstract}

KEY WORDS: tooth organ engineering, mesenchymal cell heterogeneity, vascularization, cell surface marker

\section{Introduction}

The implantation of cultured re-associations between embryonic dental epithelial and mesenchymal cells allows the development of the whole tooth organ, including crown and root formation, as well as the functional differentiation of odontoblasts, ameloblasts and cementoblasts (Hu et al., 2006; Honda et al., 2008; Nait Lechguer et al., 2011; Oshima et al., 2011). Among the parameters used to follow tooth formation during these in vitro and implantation steps, the histogenesis of the epithelial compartment is a very important one to document the biomimetic progression of the re-associations (Hu et al., 2006). However, histology allows neither evaluating the diversity of mesenchymal cells during tooth engineering, nor a straight comparison with what happens physiologically during tooth development. Since the mesenchyme controls tooth morphogenesis and epithelial histogenesis, a better knowledge of this tissue may be essential to select non dental cell sources for tooth engineering (Ohazama et al., 2004; Arany et al., 2009; Keller et al., 2011).

The existence of different cell types with distinct functions in the dental and peridental mesenchyme has been demonstrated by different approaches (Chai et al., 2000; Farges et al., 2003; Balic et al., 2010; Feng et al., 2011; Rothova et al., 2011). Since the pioneer work by Gronthos et al., 2000), different cell surface markers are currently used to fractionate cells from the dental or peridental mesenchyme, as well as to follow their phenotype during further expansion in vitro (Shi and Gronthos 2003; Nakashima et al., 2009; Balic et al., 2010; Bakopoulou et al., 2011). However, neither the localization of the cells expressing these antigens,

Abbreviations used in this paper: $\mathrm{CD}$, cluster differentiation; ED, embryonic day; GFP, green fluorescent protein; PN, post-natal; SMA, smooth muscle actin; Sca-1, stem cell antigen-1.

*Address correspondence to: Hervé Lesot. INSERM UMR 977, Faculté de Médecine, 11, Rue Humann, 67085 Strasbourg Cedex, France.
Tel: +33-3-6885-3111. Fax: +33-3-6885-3379. E-mail: lesot@ unistra.fr

Supplementary Material (figures and table) for this paper is available at: http://dx.doi.org/10.1387/ijdb.120076hl

Accepted: 13 August 2012 Final, author-corrected PDF published online: 13 November 2012.

ISSN: Online 1696-3547, Print 0214-6282

() 2012 UBC Press

Printed in Spain 
nor the sequence of their appearance during development, has been investigated. The aim of the present work was to visualize the cell diversity in the mesenchyme of teeth forming from cell reassociations and to compare it with the situation in teeth developing in situ. For that purpose, the expression of cell surface markers in the mesenchyme was investigated in three different contexts: 1) embryonic mouse first lower molars at embryonic day 14 (ED14), as representing the cell source currently used for re-associations, 2) cell re-association cultured for eight days, thus just before their implantation, to be compared to mouse molar germs at ED18, and 3) cultured cell re-associations implanted for two weeks, which would correspond to a mouse first lower molar at post-natal day 4 (PN4). After implantation, cell re-associations became vascularized and the blood vessels are coming from the host (Nait Lechguer et al., 2008). Since vascularization might allow host cells to enter and participate in the dental mesenchyme formation, re-associations were implanted in GFP mice and combinations of double stainings were performed to search for the origin of the different cell types.

\section{Results}

\section{Cell re-associations and tooth organ engineering}

To adjust to a previously established protocol (Hu et al., 2006; Nait Lechguer et al., 2011), tooth formation was investigated when culturing re-associations between dissociated single cells from embryonic (ED14) dental mesenchyme and epithelium (Fig. $1 A-D)$. After 8 days in vitro, cultured cell re-associations showed tooth crown formation, complete epithelial histogenesis, cusp formation, and the first differentiated odontoblasts facing preameloblasts (Fig. 1G). This development corresponded to that of a first lower molar at ED18 in situ (Fig. 1F). Further development proceeded when these cultured re-associations were implanted subcutaneously in adult mice for two weeks (Fig. 1K). At that stage, the engineered teeth showed gradients of functionally differentiated odontoblasts secreting pre-dentin and dentin and ameloblasts secreting enamel (Fig. 1K). At that stage the root development had been initiated as well (Fig. 1K). These features corresponded to molar development as observed at PN4 in situ (Fig. 1J). When

Fig. 1. Protocol for tooth organ engineering and comparison with tooth development. First lower molars (B) were dissected from mouse embryos at ED14(A). The epithelium (C) and ecto-mesenchyme (D) were then separated. Each tissue was dissociated into single cells, which were then re-associated and grown on a semi-solid cultured medium. After 8 days in vitro, which allowed crown formation (G), cell re-associations were implanted subcutaneously in an adult mouse to lead to a complete tooth (K). When ED14 mesenchymal single cells were cultured in monolayer (E) before their re-association with an intact dental epithelium (H), these cells lost their potential to form tooth in vitro (I). The development of cultured (G) and implanted $(\mathbf{K})$ cell re-associations corresponded to developing teeth at ED18 (F) and PN4 (J), respectively.
ED14 dental mesenchymal single cells (Fig. 1E) were cultured prior to re-association with an intact ED14 epithelial tissue (Fig. $1 \mathrm{H}$ ), no tooth developed after 6 days in vitro (Fig. 1I). Indeed, no sign of epithelial histogenesis or dental cell differenciation could be observed in these conditions (Fig. 1I).

\section{Mesenchymal material used for cell re-associations}

The question of the delimitation of the mesenchyme and thus the amount of peridental tissue used to prepare cell re-associations had been raised by Rothova et al. (2011), when discussing our previous experiments (Nait Lechguer et al., 2008). To address it, immunostainings were performed on molars isolated from the lower jaw at ED14 (Fig. 1B). The mesenchymal compartment used as a cell source for re-associations included the highly vascularized area, which surrounds the tooth germ. Thus, the initially CD31-, CD34- and CD146-positive cells were used for the re-associations (Fig. 2A-C). $\alpha$-SMA, Sca-1, CD45, CD90 and CD73 were not expressed in the mesenchyme at ED14 (Fig. 2D-G). Except for CD31, which was lost at the onset of the monolayer culture (Fig. $2 \mathrm{H}, \mathrm{O}, \mathrm{V})$, all the cell surface markers started to be expressed by dissociated mesenchymal cells when cultured as a monolayer (Fig. 2I-N, P-U, W-Z').

\section{Expression of cell surface markers during in situ tooth development}

The heterogeneity of the dental pulp cells was investigated during in situ mouse tooth development, from the cap stage at ED14 to PN4. Blood vessels and pericytes were visualized by immunostaining for CD31, CD34, CD146 and $\alpha$-SMA. Vascularization started in the condensed dental mesenchyme at the cap stage, forming a dense

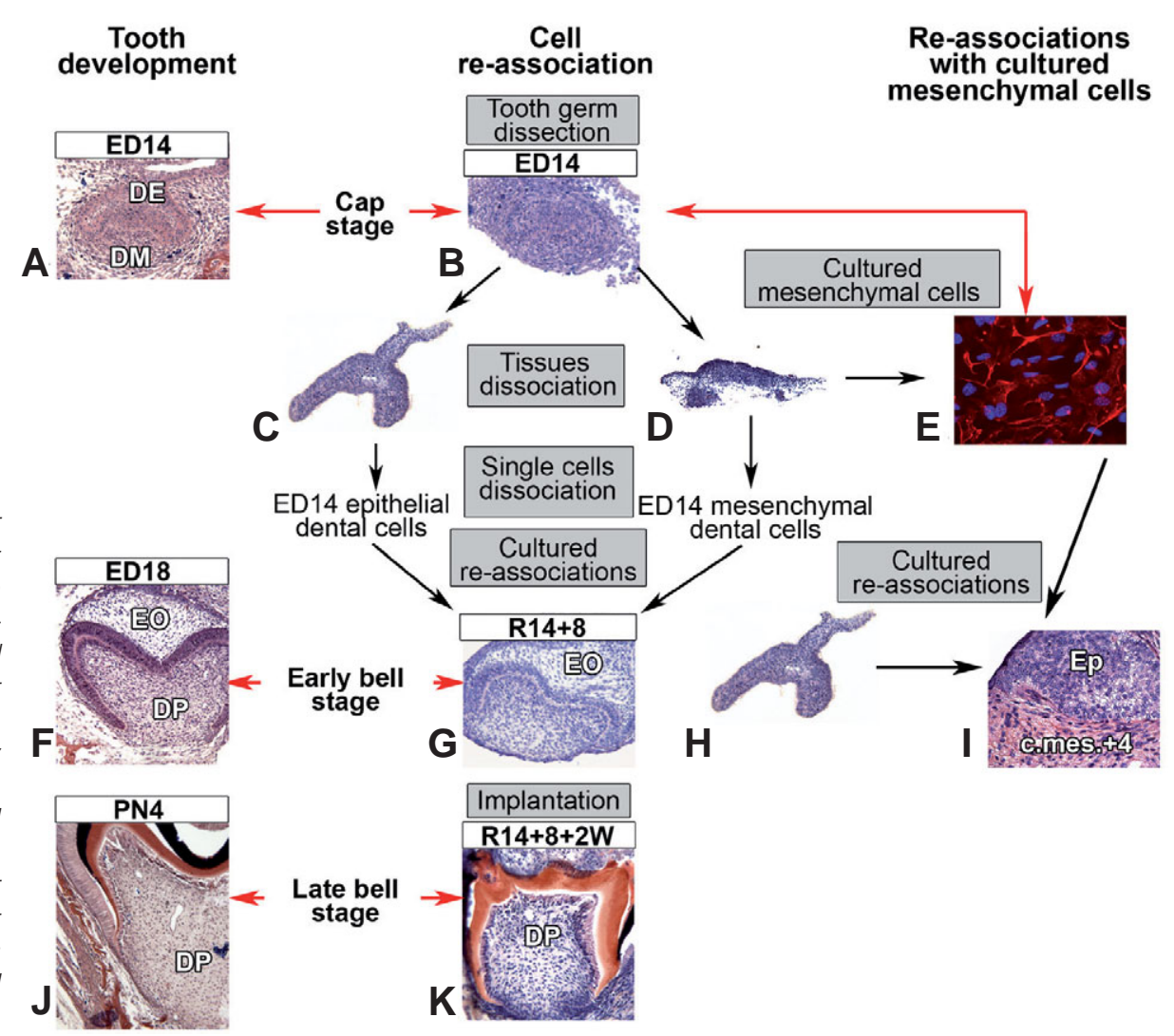


network surrounding the dental and peridental mesenchyme (Fig. $3 A-C)$. Blood vessels reached the sub-odontoblastic cell layer at the bell stage (ED18) (Fig. 3E-G). Between PN1 and PN4, capillaries reached the odontoblast layer (Fig. 3I-K, M-O). After staining for $\alpha$-SMA to search for pericytes, positive staining in the dental mesenchyme was not detected until PN4 (Fig. 3M, Q). Even at that stage, very few pericytes were visualized, mostly in the apical part of the pulp. At the periphery of the condensed mesenchyme at ED14, only few cells were Sca-1 positive (Fig. 1D). In the dental pulp, the first few cells positive for Sca-1 appeared at PN1 (Fig. 1L), while still absent at ED18 (Fig. 1H). At PN4, this cell surface marker could be detected in association with large blood vessels at the apical part of the pulp (Fig. 3P). Indeed, in this location, two types of Sca-1

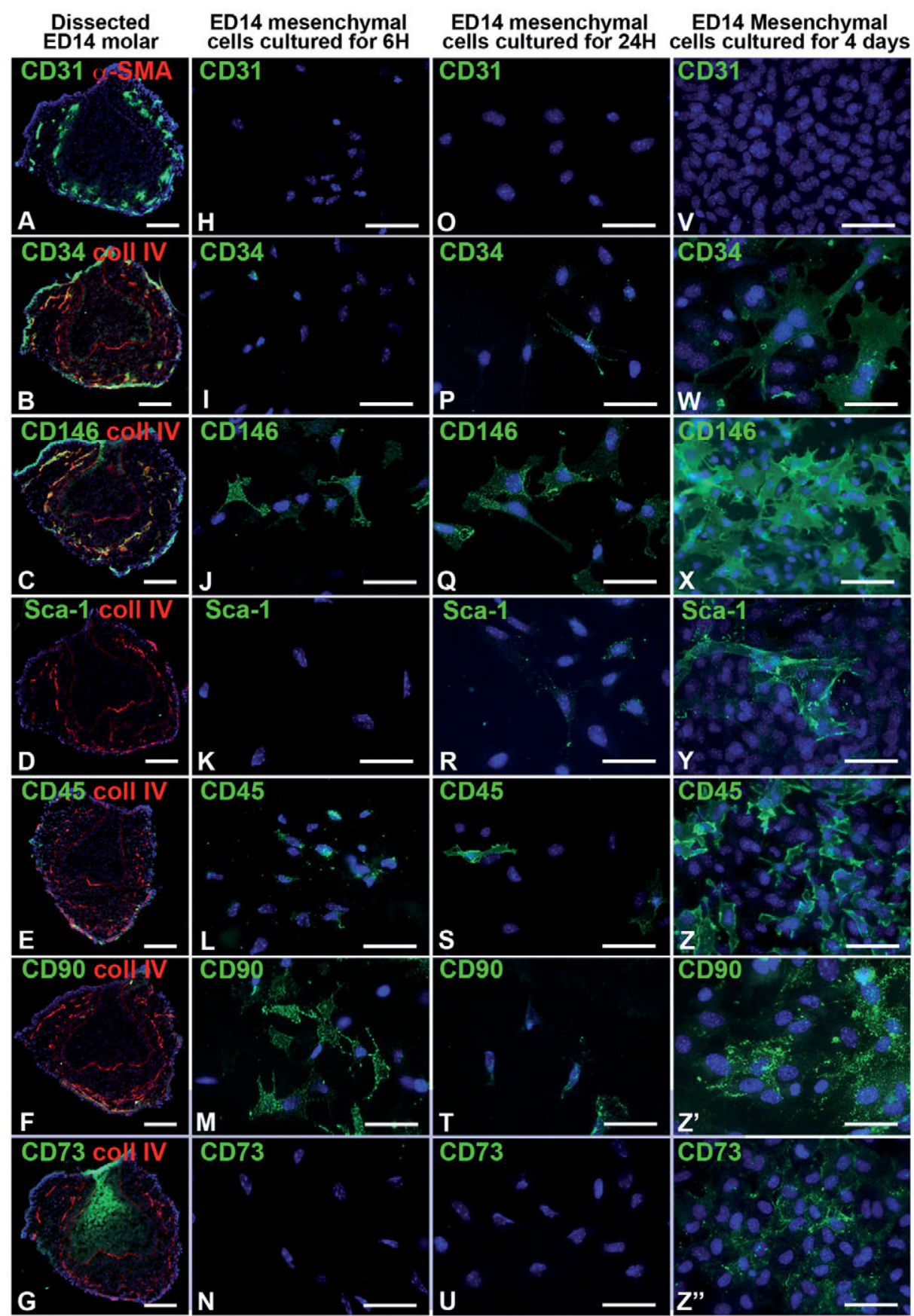

positive cells could be observed: some which co-localized with the CD31 blood vessel marker, and the others, negative for CD31 were located in the perivascular region (Fig. 3 R-T).

Whatever the stage was, cells associated with the blood vessels remained negative for CD45 (Fig. 4Q,) and for CD73 (Fig. $4 \mathrm{~L})$. Very few CD45 positive cells were detected at the periphery of the condensed mesenchyme at ED14 (Fig. 4A). Their number increased at the bell stage, mainly in the peridental mesenchyme (Fig. 4B). In the dental pulp, the number of CD45 positive cells further increased from ED18 to PN4 (Fig.4B-D). The pattern of CD45 positive cells was clearly distinct from that of blood vessels (Fig. 4A-D, Q). CD90 was detected in the peridental mesenchyme at ED14, showing a strong asymmetric staining on the buccal side of the tooth (Fig. 4E). At the bell stage (ED18), cells positive for CD90 were detected in the upper part of the dental pulp and later in most of the dental pulp (Fig. 4F-H). However, the odontoblasts remained negative for CD90 at PN4 (Fig. 4M, see Fig. S1 in supplementary material) and the staining was stronger in the vicinity of blood vessels (Fig. $4 \mathrm{O}, \mathrm{P}$ ). At the cap stage, CD73 was detected in the dental epithelium, but the mesenchyme remained completely negative (Fig. 4I). From ED18 to PN4, the outer dental epithelium was positive for CD73 (Fig. $4 \mathrm{~J}$-L). During this period, the peridental mesenchyme was also positive for CD73 (Fig. $4 \mathrm{~J}-\mathrm{L}$ ). Only at PN4, odontoblasts became positive for CD73 (Fig. 4L, N).

\section{Expression of cell surface markers in cultured cell re-associations}

Cell re-associations were cultured for 8 days on a semi-solid medium before their subcutaneous implantation in adult mice (Fig. 1). At the end of this culture period, cell re-associations reached the early bell stage (Fig. 1G). Immunostainings for CD31, CD34 or $\alpha$-SMA remained negative (Fig. $5 \mathrm{~A}, \mathrm{~B}$ ). CD146 was detected in the dental epithelium, but not in the dental pulp (Fig. 5C). Sca-1 was not detected in the re-associations (Fig. 5D). The cells of the peridental mesenchyme were positive for CD73 (Fig. 5G). As also observed

Fig. 2. Cell surface marker heterogeneity in the dental mesenchyme at ED14 (A-G) and ED14 dental mesenchymal single cells grown as monolayer ( $\left.\mathbf{H}-\mathbf{Z}^{\prime \prime}\right)$. Immunostaining of $\alpha-S M A$ (A), collagen IV (B-G) in red and cell surface markers CD31 (A), CD34 (B), CD146 (C), Sca-1 (D), CD45 (E), CD90 (F) and CD73 (G) in green Immunodetection in green of $C D 31(\mathbf{H}, \mathbf{O}, \mathbf{V})$ CD34(I,P,W), CD146 (J, Q, X), Sca-1 (K,R, Y), CD45 (L,S,Z), CD90 (M,T,Z') and CD73 (N,U,Z") after 6 hours (H-N), 24 hours (O-U) and 4 days (V-Z") in vitro. Antibodies to collagen IV, used to visualize the dental epithelial-mesenchymal junction, also stained the basement membrane of blood vessels (B-G). Scale bars: $50 \mu \mathrm{m}$ (H-Z") and $100 \mu \mathrm{m}$ (A-G) 


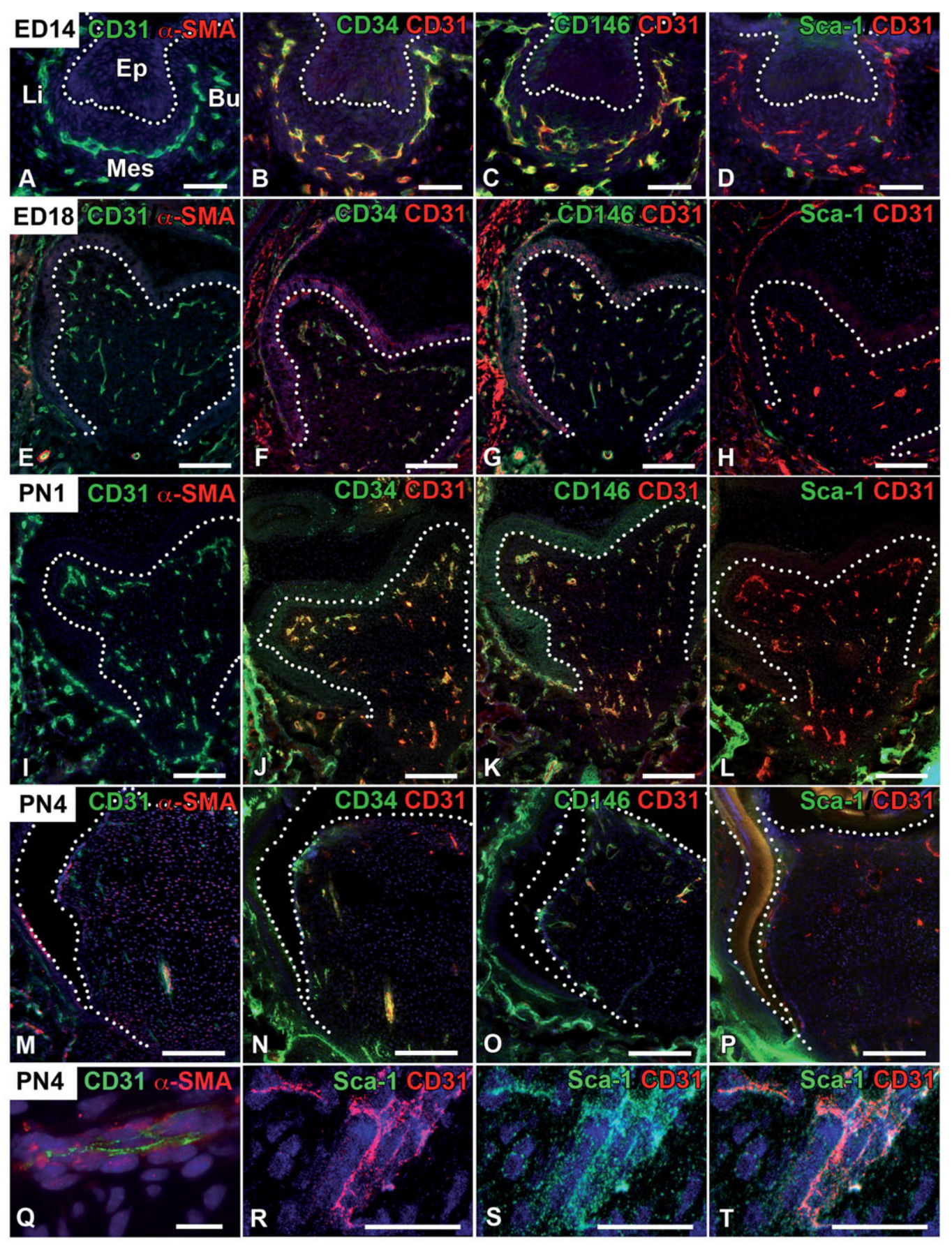

Fig. 3. Cellular heterogeneity in the molar dental and peridental mesenchyme during tooth development: cell surface markers associated with blood vessels. $C D 31$ (A-T), $\alpha-S M A$ $(\mathbf{A}, \mathbf{E}, \mathbf{F}, \mathbf{I}, \mathbf{M}, \mathbf{Q}), C D 34(\mathbf{B}, \mathbf{F}, \mathbf{J}, \mathbf{N}), C D 146$ (C, G,K, $\mathbf{O})$ and Sca-1 (D,H,L,P,R-T) were observed in CD-1 mice at different stages of tooth development: the ED14 cap stage (A-D), the ED18 early bell stage (E-H), and late bell stages at PN1 (I-L) and PN4 (M-T). Scale bars: $30 \mu \mathrm{m}$ (Q-T), $50 \mu \mathrm{m}$ (A-D) and $150 \mu \mathrm{m}$ (E-P).

present in the whole dental pulp of the regenerated tooth organ and reached the odontoblast layer (Fig. $6 \mathrm{~A}, \mathrm{~B}, \mathrm{~F}, \mathrm{G}, \mathrm{K}, \mathrm{L})$. In the lower part of the dental mesenchyme mainly, blood vessels were surrounded by $\alpha$-SMA positive cells (Fig. $6 A$, $B, R)$. Sca-1 positive cells were detected in the perivascular region mostly in association with the main blood vessels, in the apical part of the dental papilla (Fig. 6P, Q). Further double staining for $\alpha$-SMA and Sca-1 showed only partial colocalization (Fig. 6O, T, see Fig. S2 in supplementary material). Many CD45 positive cells were present in the dental pulp (Fig. 6C, D). They were in contact with blood vessels but remained distinct from endothelial cells (Fig. 6S). CD45 positive cells were in contact with odontoblasts (Fig. 6D, S). The specific dendritic shape of these cells (Fig. 6D, S) was better visible in monolayer cultures (see Fig. S3 in supplementary material). Many CD90 positive cells were present in the dental papilla (Fig. $6 \mathrm{H}, \mathrm{I}$ ). These cells did not co-localize with the CD31 blood vessel marker (Fig. $6 \mathrm{I}$, see Fig. S1 in supplementary material). The odontoblast layer remained negative for CD90 (Fig.

in situ at the bell stage (Fig. 4B, F), only a few cells in the dental pulp expressed CD45 (Fig. 5E, H) and CD90 positive cells were found in the upper part of the dental pulp (Fig. 5F, I).

\section{Implanted cell re-associations allowing tooth organ engineering}

The cultured cell re-associations were implanted for 2 weeks under the skin of adult nude or ICR mice allowing the functional differentiation of odontoblasts and ameloblasts, the vascularization of the tooth and the initiation of root formation (Fig.1K). The developmental stage of these re-associations corresponded to that of a developing first lower molar at PN4 (Compare Fig. 1 K with Fig. 1J).

Blood vessels, positive for CD31, CD34 and CD146, were
6J). The staining for CD73 also did not co-localize with the blood vessels (Fig. 6M, N). The odontoblasts were positive for CD73 (Fig. $6 \mathrm{~N}, \mathrm{E})$. There was also a labeling in the outer dental epithelium (Fig. 6M). After implantation, the heterogeneity of the pulp in the regenerated tooth organ was the same as in the first lower molar at PN4 in situ. The expression of cell surface markers was similar after implantation in Nude (Fig. 6) and ICR mice (not shown).

\section{Implantation in GFP mice}

To evaluate the possible contribution of the host to the pulp cell heterogeneity, cultured cell re-associations were implanted under the skin of GFP mice. One week after the implantation, GFP posi- 
tive cells in the pulp included CD146 (Fig. 7A-C), Sca-1 (Fig. 7 G-I) and CD90 positive cells (Fig. 7M-O). However, not all the CD90 and Sca-1 positive cells were coming from the host. Indeed, some CD90 and Sca-1 positive cells in contact with blood vessels could also be GFP-negative (Fig. 7G-I, M-O). After two weeks of implantation, $\alpha$-SMA positive cells could be observed in the implants (Fig. 6A, B; Fig. 7D-F). These pericytes were positive for GFP (Fig. 7 D-F). CD45 positive cells were always GFP negative (Fig. $7 \mathrm{~J}-\mathrm{L}$ ).

\section{Discussion}

\section{Changes in mesenchymal cell heterogeneity during tooth development}

During tooth development, specific stages of epithelial histogenesis have been investigated in detail (for review, see Lesot and Brook, 2009). Much less is known about the mesenchyme although a parallel specification of this tissue can be expected. Classical histology allows a quite precise follow up of odontoblast differentiation and progressive vascularization. Knowledge of the innervation was facilitated by the use of specific probes and anti-
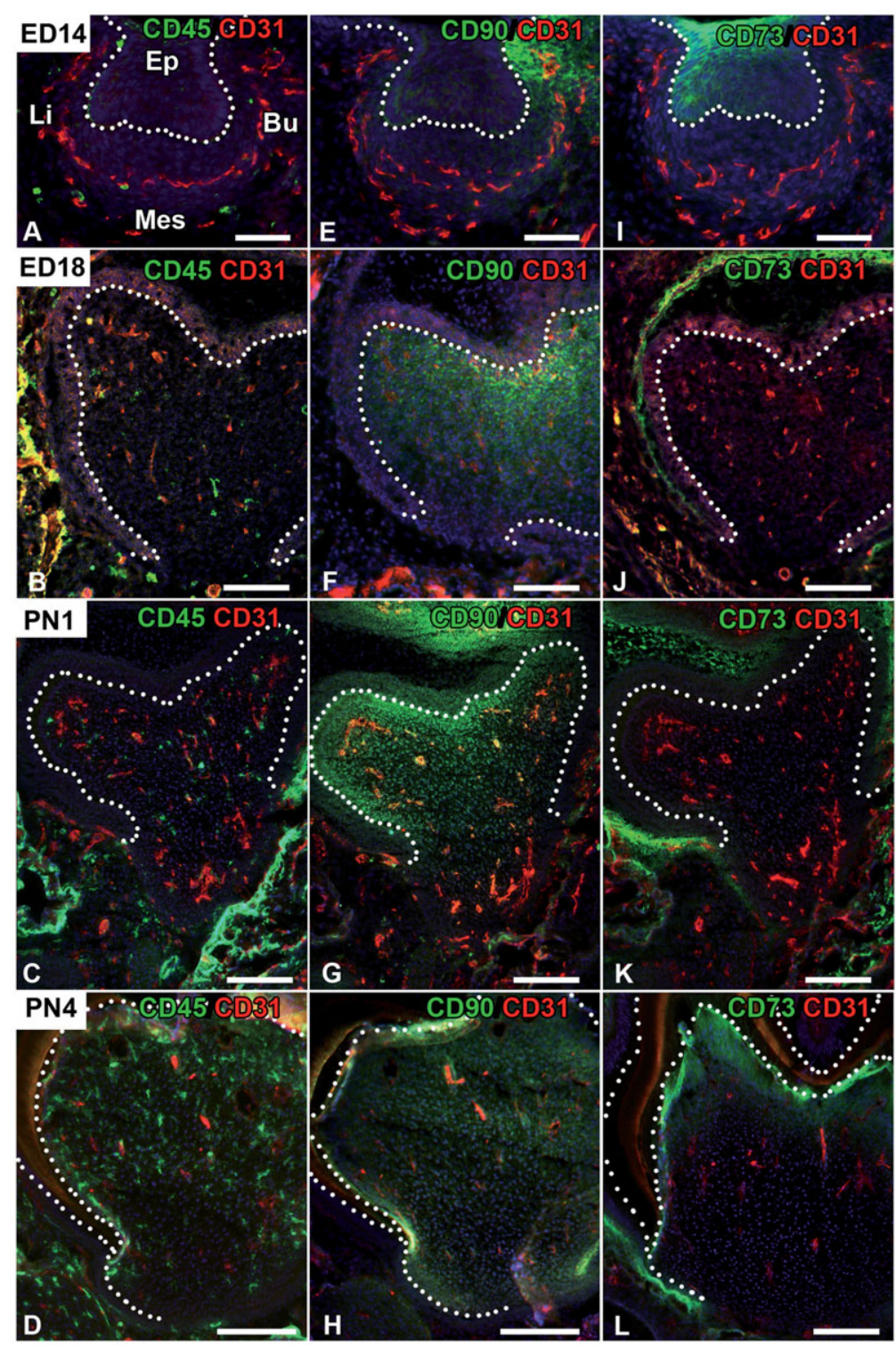

bodies (Fried et al., 2005; Moe et al., 2008). More recently, several different cell surface markers have been used to separate dental mesenchymal cells, mostly to search for stem cells (Karaöz et al., 2010; Balic and Mina, 2010; Atari et al., 2012). These studies clearly showed that several different cell populations exist both in the dental and peridental mesenchyme. However, very little is known about their location and sequence of appearance during tooth development and nothing in case of cell re-associations. In order to address this question and try to determine how far the culture and further implantation of cell re-associations would allow mimicking physiological tooth development, immunostainings of such re-associations were performed using a series of antibodies for surface markers and were compared with results obtained for tooth germs at different stages of development.

The detection of surface markers allowed visualizing this cell heterogeneity and the existence of distinct patterns. The different cell populations also showed a differential timing in their appearance during tooth development. While CD31, CD34 and CD146 were expressed in the blood vessels surrounding the molar at the early cap stage (ED14), they were detected in the whole dental

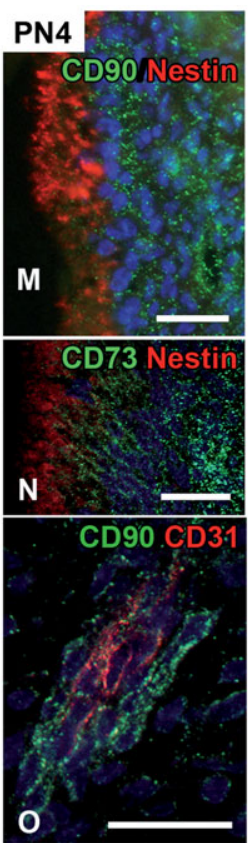

CD90.CD́31

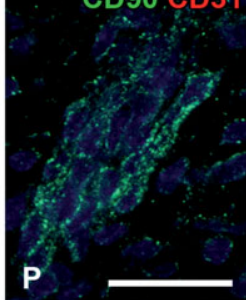

CD45 CD31 mesenchyme at ED18, underlying the odontoblast layer. At ED18 also, CD45 positive cells were detected in the dental and peridental mesenchyme, while CD90 positive cells were restricted to the dental mesenchyme. CD45 was expressed by cells exhibiting a typical dendritic morphology, better seen in monolayer culture (see Fig. S3 in supplementary material). Several dendritic cell types resident or not exist in the dental mesenchyme (Zhang et al., 2006; Okiji, 2012). They include immunocompetent cells, which can be recruited to participate in reparative processes (Jontell et al., 1998; Farges et al., 2003; Goldberg et al., 2008). From the postnatal day-1 (PN1), Sca-1 was detected in the dental mesenchyme, but still very few positive cells were visualized. At PN4, this antigen was mainly restricted to the largest blood vessels at the apical part of the dental mesenchyme. Although currently used as a marker to separate stem cells, very little is known about the function of Sca-1 (Holmes and Stanford, 2007). Cells expressing this antigen may

Fig. 4. Cellular heterogeneity in the molar dental and peridental mesenchyme during tooth development: cell surface markers expression not related with the vascularization. Immunodetection of CD45(A-D,0), CD90 (E-H,M,O,P) and CD73(I-L,N) was performed at the ED14 cap stage (A,E,I), the ED18 early bell stage $\mathbf{( B , F , J ) , ~ a n d ~ l a t e ~ b e l l ~ s t a g e s ~ a t ~ P N ~} 1(\mathbf{C}, \mathbf{G}, \mathbf{K})$ and PN4 (D, $\mathbf{H}, \mathbf{L}-\mathbf{Q})$. Nestin, an intermediate filament constituent present in odontoblast was used as a marker for these functional cells (M,N). Scale bars: $30 \mu \mathrm{m}$ (M-Q), $50 \mu \mathrm{m}$ (A,E,I) and $150 \mu \mathrm{m}$ (B-D,F-H,J-L). 


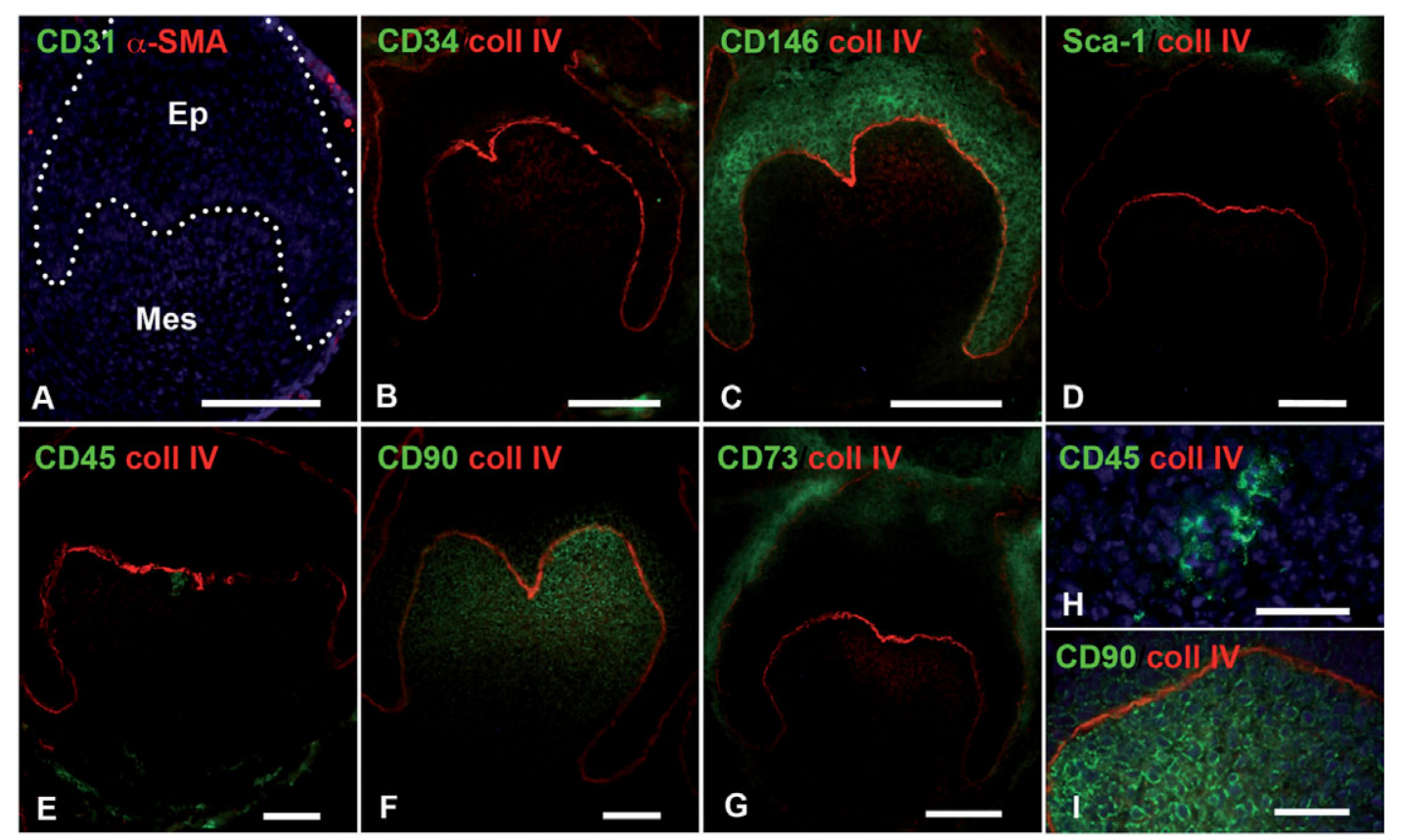

Fig. 5. Cell surface marker heterogeneity in the dental and peridental mesenchyme of engineered teeth before implantation and vascularization. Double staining for CD31 and $\alpha$-SMA(A) or collagen IV in red (B-I) with CD34 (B), CD146(C), Sca-1(D), CD45(E, $\mathbf{H}), C D 90(\mathbf{F}, \mathbf{I}), C D 73(\mathbf{G})$ in green in cultured cell re-associations just before implantation in mice. Scale bars: $10 \mu \mathrm{m}$ (A-G), $20 \mu \mathrm{m}$ (H, I). participate in regenerative processes as shown mostly for repair and re-vascularization of cardiac tissue (Wang et al., 2006; Iwasaki et al., 2011). At PN4, $\alpha$-SMA positive cells were found in close contact with the main blood vessels, mostly in the apical part of the dental mesenchyme. At this stage also, odontoblasts became positive for CD73. CD73 is a 5'nucleotidase, and its expression might be related to the functional state of odontoblasts. Both this 5 'nucleotidase and alkaline phosphatase use AMP as a substrate (Andrade et al., 2008) and could play a role in the expression of osteocalcin (Bidder et al., 1998; Takedachi et al., 2012). Odontoblasts were transiently positive for CD90 at PN1 and negative again at PN4. The late appearance of cells expressing CD45, Sca-1, $\alpha$-SMA and CD73 in the pulp illustrates a progressive change in the heterogeneity of these cells during tooth development. This might be a consequence of either a specification of mesenchymal cells mediated by epithelial-mesenchymal interactions during odontogenesis, or from the contribution of exogenous cells entering the mesenchyme after it became vascularized (Chai et al., 2000; Nait Lechguer et al., 2008; Rothova et al., 2011; Feng et al., 2011). Furthermore, cell re-associations, which had been cultured for 8 days and then implanted for two weeks, reached the developmental stage of a first lower molar at PN4 in situ (Nait Lechguer et al., 2011). Both in PN4 molars and implanted cell re-associations, a complex heterogeneity was observed, with very similar patterns of staining in the two types of samples (see Table S5 in supplementary material).

\section{Phenotypic changes in vitro}

For tooth organ engineering, attempts are made to use clonal cell lines or iPS instead of dental embryonic cells and it is necessary to expand these cells prior to re-association (Arany et al., 2009; Keller et al., 2011; Otsu et al., 2012). Expansion in vitro leads to major changes given the tissue organization is lost. Original cell-cell

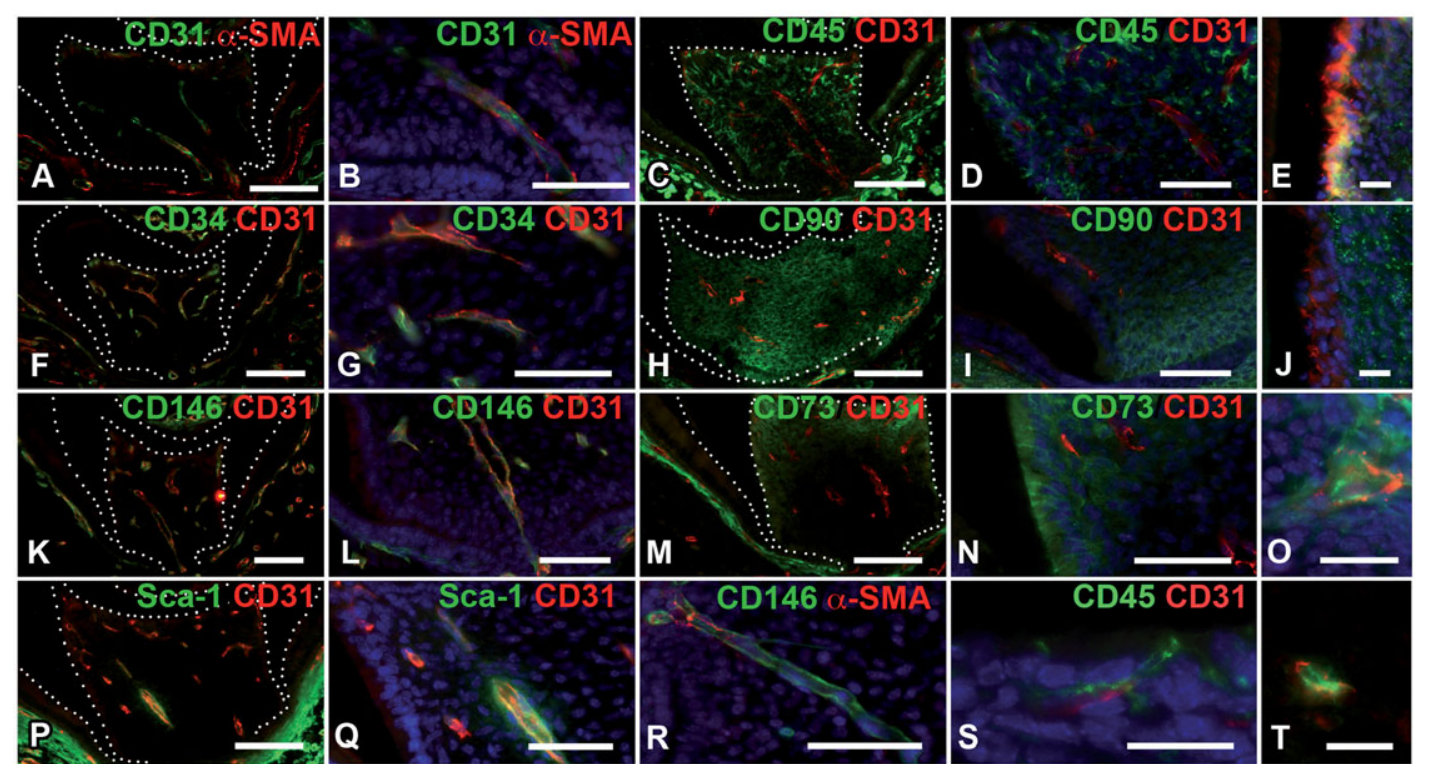

Fig. 6. Cellular heterogeneity in the dental and peridental mesenchyme engineered tooth organ. Double stainings for CD31 (A-D,F-I,K-N,P-S) and $\alpha-S M A(\mathbf{A}, \mathbf{B})$ or CD34 (F,G), CD146 (K,L), Sca-1 $(\mathbf{P}, \mathbf{Q}), C D 45(\mathbf{C}, \mathbf{D}, \mathbf{S}), C D 90(\mathbf{H}, \mathbf{I})$ and $\mathrm{CD73}(\mathbf{M}, \mathbf{N})$ in cultured re-associations implanted for 2 weeks in nude mice. High mignifications showed the co-localization of $\alpha$-SMA with CD146 (R) and also $\alpha$-SMA with Sca-1 $(\mathbf{O}, \mathbf{T})$. Odontoblasts, positive for nestin in red $(\mathbf{E}, \mathbf{J})$, expressed CD73 (E), but not CD90 (J). Scale bars: $20 \mu \mathrm{m}$ (E,J,O,S,T), $50 \mu \mathrm{m}$ $(\mathbf{B}, \mathbf{D}, \mathbf{G}, \mathbf{I}, \mathbf{L}, \mathbf{N}, \mathbf{Q}, \mathbf{R})$ and $100 \mu \mathrm{m}$ $(\mathrm{A}, \mathrm{C}, \mathrm{F}, \mathrm{H}, \mathrm{K}, \mathrm{M}, \mathrm{P})$. 
communications no longer exist and new cell-matrix interactions form when cells are grown as a monolayer, which involves many different cell surface constituents. It is not sure then that the different cell types present in the mesenchyme at ED14 can all adjust to this new environment. Attempts were thus made to investigate the phenotype of cultured embryonic dental mesenchymal cells. After being cultured as monolayers for 4 days, ED14 mesenchymal cells indeed showed a very different phenotype when compared to mesenchymal cells used directly for cell re-associations (see Table S5 in supplementary material).

Initially, CD31, CD34 and CD146 positive cells were present in the mesenchyme at ED14. In opposition to CD146, CD31 and CD34 were no longer detected when dental mesenchymal cells were cultured alone in vitro for only 6 hours. For longer culture periods, CD34 was re-expressed, but not CD31 and the proportion of positive cells for CD34 and CD146 increased with time, as reported also for other surface markers for mesenchymal cells from erupted molars (Balic et al., 2010). This demonstrated the instability of mesenchymal cell phenotype in vitro, even without passage, and also very distinct fates for the different markers. Furthermore, these three antigens could no longer be detected in the mesenchyme of re-association cultured for 8 days, just before their implantation. This illustrated further difference when comparing mesenchymal cells cultured alone as a monolayer or organized as a tissue when re-associated with dental epithelial cells (see Table S5 in supplementary material). These differences might result either from the lack of epithelial-mesenchymal interactions or from major environmental changes when tissue organization was disrupted and single cells were grown in vitro ( $\mathrm{Lu}$ et al., 2012). Changes related to the experimental conditions were also observed when looking at the expression of Sca-1 and CD73. The two antigens were absent from the mesenchyme at ED14, but started to be expressed when the mesenchymal cells were cultured alone, and the number of positive cells increased with the culture duration. These observations illustrate the question of phenotype instability in vitro, to be solved when trying to use expanded cells for tooth engineering (Volponi et al., 2010; Kuchler-Bopp etal., 2011). In most cases, when expanding stem cells, the cell phenotype was evaluated between distant passages (Horii et al., 2010; Pei et al., 2011; Lee et al., 2012). However, our data show that fundamental changes may occur very early, during the first 24 hours in a primary culture. The change in the phenotype or in the balance of cell

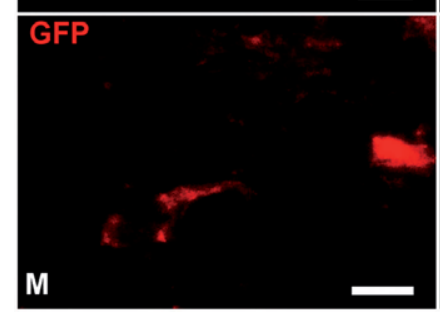

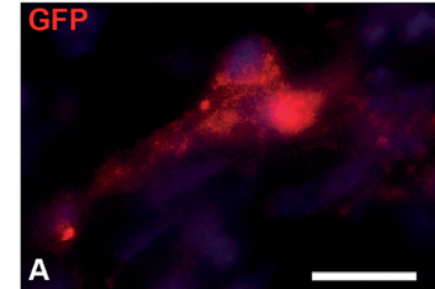
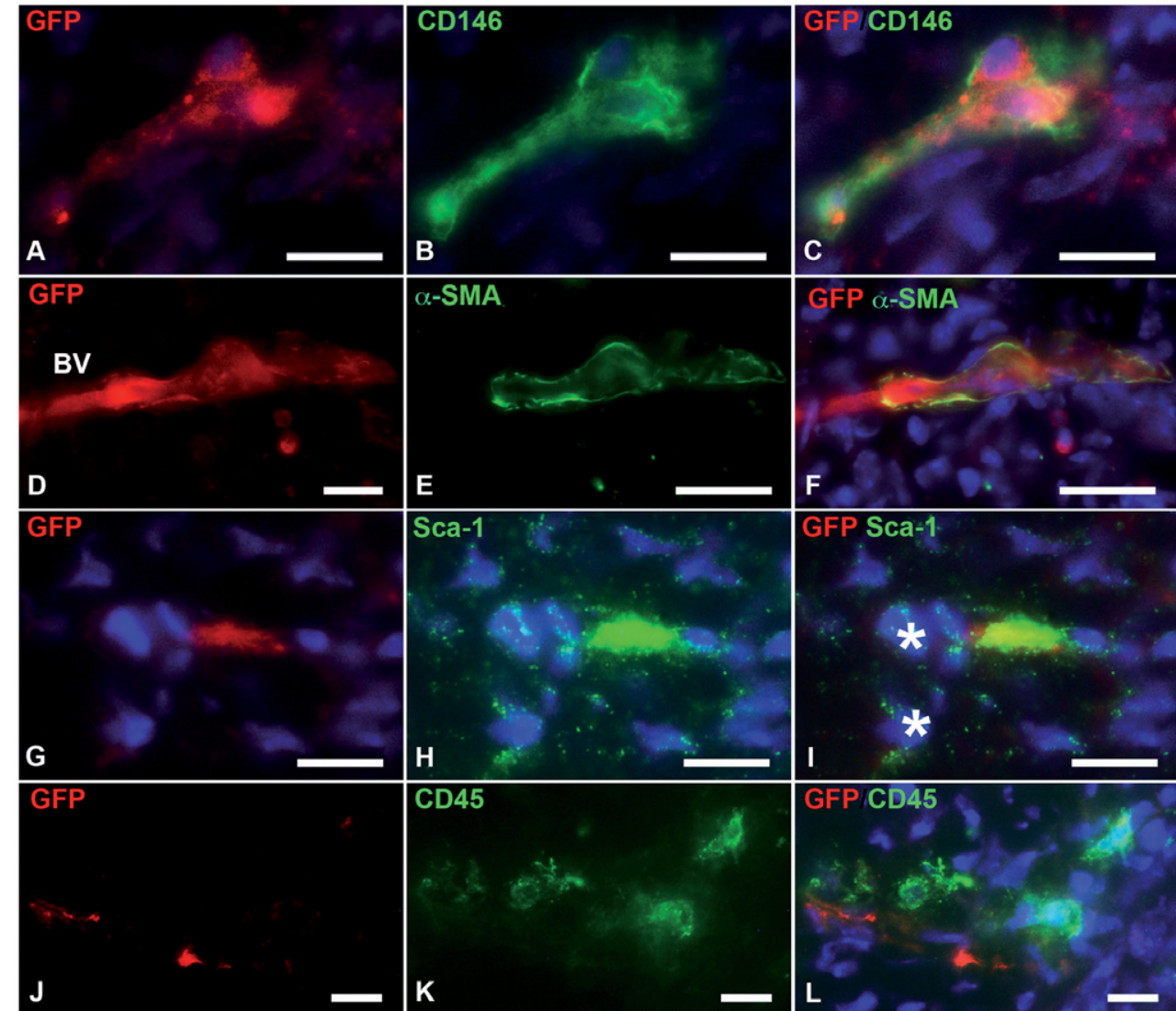

opulations during expansion might explain the loss of odontogenic potential by cultured cells, as observed already after $24 \mathrm{~h}$ only (Keller et al., 2011). The phenotypic instability of dental mesenchymal cells in vitro has already been reported when using very different criterion such as telomere attrition (Mokry et al., 2010). Since it has also been paralleled with a loss of differentiation potential, the optimization of culture conditions to allow cell expansion still remains a major challenge for tooth engineering (Patel et al., 2009; Yu et al., 2010; Pei et al., 2011).

\section{Cells from different origins are present in the dental mesen- chyme}

The present observations showed that, although CD31, CD34 and CD146 are expressed in situ by the mesenchymal cells used for re-associations, they were no longer expressed in the dental mesenchyme of these re-associations, when cultured for 8 days
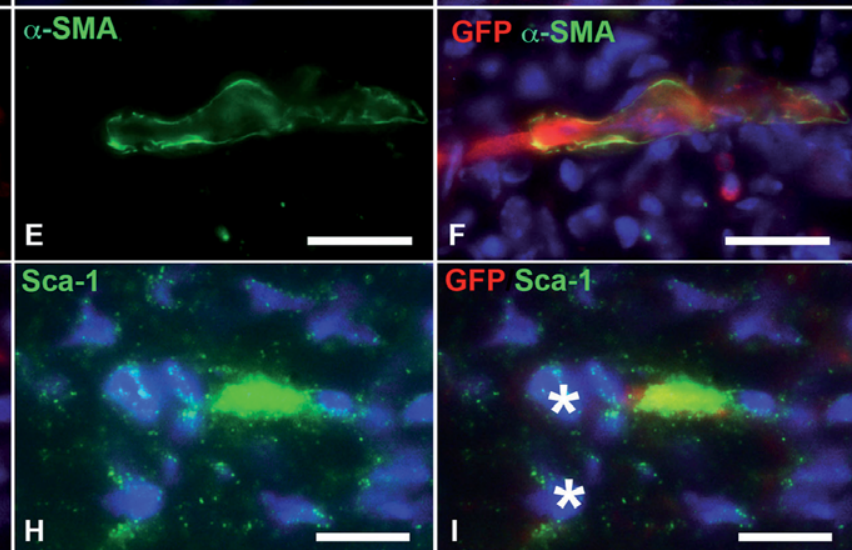

Fig. 7. Host cellular participation in mesenchymal cell heterogeneity in the engineered tooth organ. Immunolocalization of GFP positive cells in red $(\mathbf{A}, \mathbf{C}, \mathbf{D}, \mathbf{F}, \mathbf{G}, \mathbf{I}, \mathbf{J}, \mathbf{L}, \mathbf{M}, \mathbf{O})$ and cell surface markers CD146 $(\mathbf{B}, \mathbf{C}), \alpha-S M A(\mathbf{E}, \mathbf{F}), C D 45(\mathbf{K}, \mathbf{L}), S c a-1(\mathbf{H}, \mathbf{I})$ and $C D 90(\mathbf{N}, \mathbf{O})$ in green in the pulp of cell-re-associations implanted in GFP mice for one (A-C,G-I,J-L,M-O) or two (D-F) weeks. White stars are located above the nucleus of cells positive for Sca-1 and negative for GFP. All Figs. from the right column correspond to overlays of Figs. from the two other columns. Scale bars: $10 \mu \mathrm{m}$. 
(i.e. prior to implantation) (see Table S5 in supplementary material). When blood vessels could not be maintained, the three antigens related to endothelial cells and pericytes were no longer detected. These data suggest that, although an initial hererogeneity exists in the mesenchyme, the first steps of odontogenesis leading to epithelial histogenesis, cusp formation and the initiation of odontoblast differentiation, do not require the participation of cells from the host, imported by the vascularization.

Previous observations after implantation of cultured tooth germs in GFP mice have shown that the implants could be re-vascularized and that this involved cells from the host (Nait Lechguer et al., 2008). The implantation of cultured cell re-associations in GFP mice performed in this study showed that the cells expressing CD31, CD34 (not shown), CD146 and later $\alpha$-SMA originated from the host. This indicated that not only endothelial cells, but also some of the cells associated with the vessel walls originated from the host.

When re-associations were cultured for 8 days, the mesenchymal cells were positive for CD90 in the dental pulp and for CD73 in the peridental mesenchyme. Few cells positive for CD45 were observed in the dental mesenchyme. In all three cases, this corresponded to what was observed in situ at a corresponding developmental stage (ED18). CD73 became expressed when molars from ED18 had been cultured for 7 days, while the antigen was absent at the onset of the culture (see Fig. S4 in supplementary material). Moreover, CD45 was detected in the mesenchyme of cultured cell re-associations although it was initially absent just before cell dissociations. These two sets of observations, in experimental conditions where there is no vascularization, demonstrate the endogenous origin of cells expressing CD45 and CD73. Indeed, the implantation of cell re-associations in GFP mice confirmed that all CD45 and CD73 positive cells are endogenous: they all were GFP negative. Even the CD45 positive cells present in the perivascular environment, as described by Okiji et al. (1997) in the human dental pulp, were GFP negative. The situation was different for CD90 or Sca-1 positive cells associated to blood vessels. These cells could be either GFP-positive or negative, indicating that, in both cases, they still consisted of heterogeneous populations, at least regarding their origins. Sca-1 positive cells were exclusively detected in association with the main blood vessels and could also be positive for $\alpha$-SMA, a pericyte marker. Bianco (2011) proposed a model related to bone organogenesis, where cells might be recruited to the perivascular environment and become progenitor cells. This might apply to the population of Sca-1 positive cells in the dental mesenchyme, which were GFP negative. It is still not known whether these cells might later be involved in reparative processes (Feng et al., 2011). However, several lines of evidence suggest the participation of dental pulp cells in reparative processes (Smith and Lesot, 2001; Farges et al., 2003; Feng et al., 2011). Further detailed investigation will be necessary to identify the cells, which are mobilized, and the signaling that is involved. Indeed, both might vary depending on the context or degree of the damage. It is not sure yet whether a single cell population or several different ones can lead to reparative odontoblast-like cells.

\section{Cell organization in the mesenchyme vs. histogenesis in the epithelium}

Except for odontoblasts and sub-odontoblast sister cells, which organize as layers, the cell organization in the mesenchyme could hardly be detected from histological sections and histogenesis there ends up with the setting of functional networks at different times of tooth formation: vascularization and innervation. In both cases the functionality of these networks involves the formation of specific heterotypic cell-cell interactions to allow the formation of perivascular niches, when blood vessels maturate or nerve/ odontoblasts interactions at the late bell stage (Carda and Peydró, 2006; Diaz-Flores et al., 2009; Magloire et al., 2010; Bianco, 2011). The stainings performed in this study allowed following the maturation of blood vessels and further illustrated the progressive spatial distribution of endogenous dendritic cells. In opposition to epithelial histogenesis, when cells organize as layers (i.e. inner and outer epithelia, stratum intermedium), or as transient clusters (i.e. primary and secondary enamel knots), dendritic cells in the mesenchyme mostly remain dispersed and isolated throughout the tissue. This pattern might be related to the possible involvement of these cells in reparative processes (Farges et al., 2003; Goldberg et al., 2008).

In conclusion, the culture of cell re-associations allows odontogenesis to progress from the bud to the bell stage although there is no vascularization (Hu et al., 2005b). However, vascularization plays an important role in restoring the cell heterogeneity in the mesenchyme as seen when comparing either cultured or implanted cell re-associations with either tooth germs in situ at corresponding developmental stages. For the same reason, the patterns of surface markers expressions were also very different in cultured versus implanted re-associations. However, since the culture period allowed a complete histogenesis in the epithelium ( $\mathrm{Hu}$ et al., 2005a), further epithelial-mesenchymal interactions allowed a reciprocal control of mesenchymal cell specification and patterning, including cells imported from the host. The distribution of the different cell types, as observed in molars in situ, could be restored after the implantation of cultured cell re-associations although, at the onset of the re-associations, the different cell types present in the mesenchyme at ED14 were completely mixed and not all cell types were present. Still, the process remains very fragile since a pre-culture of the dissociated mesenchymal cells for 24 hours before their re-association abrogates further tooth development (Keller et al., 2011). Even if the vascularization plays an active role in mediating the mesenchymal cell heterogeneity, it is not sufficient to make mesenchymal cell lines become competent to form a tooth (Keller et al., 2011). Implanted cell lines failed to form teeth despite the vascularization of the implants and thus a possible supply of missing signaling molecules, or the income of exogenous cells competent to engage in tooth formation (Keller et al., 2011). Immunostainings for cell surface markers showed that indeed rapid changes occurred when comparing cultured mesenchymal cells with their counterpart in intact tooth germs. Further work will be necessary to determine whether these phenotypic changes may result either from a cell selection or from alterations in environmental conditions. However, the rapidity of the changes, which occur in vitro, would favor the second hypothesis

\section{Materials and Methods}

\section{Cell re-associations and in vitro culture}

First lower molars were dissected from CD-1 mouse (Charles River Laboratories, l'Arbesle, France) embryos at ED14 under a stereomicroscope (Leica MZ9,5, Nanterre, France). To stage embryos, the day when a vaginal plug was detected was considered EDO. All procedures were in compliance with the recommendations of the European Economic Com- 
munity (86/609/CEE) on use and care of laboratory animals. Epithelial and mesenchymal constituents of each molar were separated by using $1 \%$ trypsin (BD Bioscience, Pont de Claix, France) in DMEM-F12 (Invitrogen, Villebon sur Yvette, France) medium at $4^{\circ} \mathrm{C}$ during 30 minutes. Then each dental tissue was further dissociated into single cells. Cells were passed through a $70 \mu \mathrm{m}$ nylon filter and centrifuged at $9000 \mathrm{~g}$ for 2 minutes (Hu et al., 2005a). The pellets containing mesenchymal and epithelial single cells were cut into fragments and then re-associated in a semi-solid medium and cultured for 8 days ( $n=49$ re-associations) at $37^{\circ} \mathrm{C}$ (Hu et al., 2005b). The semi-solid medium consisted of DMEM-F12 (Invitrogen) containing 20 $\%$ FBS (PAA, Les Mureaux, France), $0.10 \mathrm{mg} / \mathrm{ml}$ of ascorbic acid (Merck, Lyon, France), $2 \mathrm{mM}$ of L-glutamine (Invitrogen), $50 \mathrm{U} / \mathrm{ml}$ of penicillin/ streptomycin (Invitrogen), and $0.36 \%$ of agar (Sigma-Aldrich, Lyon, France). The medium was changed every two days.

\section{Subcutaneous implantation}

After 8 days in vitro, cultured cell re-associations were implanted subcutaneously behind the ears of CD-1 $(n=186)$ or nude (CD-1) $(n=$ 6) adult mice (Charles River Laboratories), between skin and muscles. Implantations $(n=30)$ were also performed in GFP mice (C57BL/6, with GFP under the control of the CMV actin promoter, IGBMC, Illkirch, France). The mice were anaesthetized by intraperitoneal injection of $100 \mathrm{mg} / \mathrm{g}$ of ketamine (VIRBAC, Centravet, Nancy, France) and $10 \mathrm{mg} / \mathrm{g}$ of Xylazine (Rompun ${ }^{\circledR} 2 \%$, Centravet). The mice were sacrificed 1 or 2 weeks later and the implanted cell re-associations were harvested for further histological analysis or immunostaining.

\section{Mesenchymal cell culture}

Dental and peridental mesenchymal tissues were prepared from ED14 first lower molars and further dissociated. Single cells were cultured (6 experiments) in a chamber slide system (BD Biosciences) in MEM (Invitrogen) supplemented with $20 \%$ FBS (PAA), $50 \mathrm{U} / \mathrm{ml}$ of penicillin/ streptomycin (Invitrogen), and $2 \mathrm{mM}$ of L-glutamine (Invitrogen). The cells were cultured for 6 hours, 24 hours, or 4 days.

\section{Fixation protocols and immunofluorescence}

Mouse embryos were obtained from pregnant CD-1 mice at ED14 ( $\mathrm{n}$ $=3$ ) and ED18 $(n=2)$. Heads of embryos were fixed in $4 \%$ paraformaldehyde at $4^{\circ} \mathrm{C}$ and then submerged overnight at $4^{\circ} \mathrm{C}$ in PBS containing $5 \%$ sucrose. Then, heads were immersed for $6 \mathrm{~h}$ at $4^{\circ} \mathrm{C}$ PBS containing $20 \%$ sucrose and finally embedded in Tissue-Tek ${ }^{\circledR}$ OCT (Agar Scientific, Saclay, France) and frozen in liquid nitrogen.

PN1 $(n=1)$ and PN4 $(n=10)$ heads were obtained after the animal sacrifice. The skin was removed and the heads were frozen in 5 methylbutane (Sigma-Aldrich) immersed in liquid nitrogen. Dissected ED14 molars, cultured and implanted cell re-associations were mounted directly in Tissue Tek OCT after a PBS wash and frozen. All frozen samples were stored at $-80^{\circ} \mathrm{C}$ before serial sections $(10 \mu \mathrm{m})$ were cut on a cryostat (Leica, $\mathrm{CM} 3000)$. The cultured ED14 mesenchymal cells were rinsed with PBS and fixed with $4 \%$ paraformaldehyde for 10 minutes at $4{ }^{\circ} \mathrm{C}$.

Indirect immunostaining was performed after tissues and cell fixation. The primary antibodies were rat monoclonal anti-mouse CD31 (1/100) (BD Pharmingen, Evry, France), rabbit polyclonal anti-mouse CD31 (1/100), rat monoclonal anti-mouse stem cell antigen-1 (Sca-1) (1/100), rabbit polyclonal anti-human smooth muscle $\alpha$-actin ( $\alpha$-SMA) (1/100), rabbit polyclonal anti-mouse collagen IV (1/400), rabbit polyclonal anti-GFP (1/500), goat polyclonal anti-GFP $(1 / 500)($ Abcam $\AA$, Cambridge, MA, USA), rat monoclonal anti-mouse CD34 (1/100), CD146 (1/100), CD45 (1/100), CD73 (1/100), CD90 (1/100) (Ozyme, Saint Quentin Yvelines, France) and rabbit polyclonal anti-mouse nestin (tebu-bio, Le Perray en Yvelines, France). The secondary antibodies were: Donkey polyclonal anti-rat conjugated to Alexa 488 (1/200), donkey polyclonal anti-rabbit IgG conjugated to Alexa $488(1 / 200)$ and Alexa 594 (1/500) and donkey polyclonal anti-goat IgG conjugated to Alexa 594 (1/500), (Invitrogen, Villebon sur Yvette, France). Actin was also visualized using phalloidin (1/200) (Invitrogen, Villebon sur
Yvette, France). Negative controls were performed with corresponding sera instead of the primary antibody.

Slides were mounted in Fluorescence Mounting medium (Dako, Trappes, France) and observed on a microscope (Leica DM4000B) equipped for fluorescence or a confocal laser microscope (Leitz, LSM510).

\section{Histology}

For histology, samples were fixed for 24 hours in Bouin-Hollande and embedded in paraffin. Serial sections $(5$ or $7 \mu \mathrm{m})$ were stained with Mallory.

\section{Acknowledgments}

The authors thank Hervé Gegout for the histology. This work was funded by the Dental School from Strasbourg University and INSERM UMR977.

\section{References}

ANDRADE CMB, ROESCH GC, WINK MR, GUIMARÃES ELM, SOUZA LF, JARDIM FR, et al., (2008). Activity and expression of ecto-5'-nucleotidase/CD73 are increased during phenotype conversion of a hepatic stellate cell line. Life Sci82:21-29.

ARANY S, KAWAGOE M, and SUGIYAMA T (2009). Application of spontaneously immortalized odontoblast cells in tooth regeneration. Biochem Biophys Res Commun 381: 84-89.

ATARI M, GIL-RECIO C, FABREGAT M, GARCÍA-FERNÁNDEZ DA, BARAJAS M, CARRASCO M, et al. (2012). Dental Pulp of the Third Molar: A New Source of Pluripotent-like Stem Cells. J. Cell Science 125: 3343-3356.

BAKOPOULOUA, LEYHAUSEN G, VOLKJ, TSIFTSOGLOUA, GAREFIS P, KOIDIS $P$, et al. (2011). Assessment of the impact of two different isolation methods on the osteo/odontogenic differentiation potential of human dental stem cells derived from deciduous teeth. Calcif Tissue Int 88: 130-141.

BALIC A, AGUILA HL, CAIMANO MJ, FRANCONE VP, and MINA M (2010). Characterization of stem and progenitor cells in the dental pulp of erupted and unerupted murine molars. Bone 46: 1639-1651.

BALIC A, MINA M (2010). Characterization of progenitor cells in pulps of murine incisors. J Dent Res 89: 1287-1292.

BIANCO P (2011). Back to the future: moving beyond « mesenchymal stem cells ». $J$ Cell Biochem 112: 1713-1721.

BIDDER M, LATIFI T, and TOWLER DA (1998). Reciprocal temporospatial patterns of Msx2 and Osteocalcin gene expression during murine odontogenesis. J Bone Miner Res 13: 609-619.

CARDA C, PEYDRÓ A (2006). Ultrastructural patterns of human dentinal tubules, odontoblasts processes and nerve fibres. Tissue Cell 38: 141-150.

CHAI Y, JIANG X, ITO Y, BRINGAS Jr P, HAN J, ROWITCH DH, et al. (2000). Fate of the mammalian cranial neural crest during tooth and mandibular morphogenesis. Development 127: 1671-1679.

DÍAZ-FLORES L, GUTIÉRREZR, MADRID JF, VARELAH, VALLADARESF, ACOSTA $E$, et al. (2009). Pericytes. Morphofunction, interactions and pathology in a quiescent and activated mesenchymal cell niche. Histol Histopathol 24: 909-969.

FARGES J-C, ROMEAS A, MELIN M, PIN J-J, LEBECQUE S, LUCCHINI M, et al. (2003). TGF-beta1 induces accumulation of dendritic cells in the odontoblast layer. $J$ Dent Res 82: 652-656.

FENG J, MANTESSO A, DE BARI C, NISHIYAMAA, and SHARPE PT (2011). Dual origin of mesenchymal stem cells contributing to organ growth and repair. Proc Natl Acad Sci USA 108: 6503-6508.

FRIEDK, SIME W, LILLESAAR C, VIRTANENI, TRYGGVASSONK, and PATARROYO M (2005). Laminins 2 (alpha2beta1gamma1, Lm-211) and 8 (alpha4beta1gamma1, Lm-411) are synthesized and secreted by tooth pulp fibroblasts and differentially promote neurite outgrowth from trigeminal ganglion sensory neurons. Exp Cell Res 307: 329-341.

GOLDBERG M, FARGES J-C, LACERDA-PINHEIRO S, SIX N, JEGAT N, DECUP $\mathrm{F}$, et al. (2008). Inflammatory and immunological aspects of dental pulp repair. Pharmacol Res 58: 137-147.

GRONTHOS S, MANKANI M, BRAHIM J, ROBEY PG, and SHI S (2000). Postnatal human dental pulp stem cells (DPSCs) in vitro and in vivo. Proc Natl Acad Sci USA 97: 13625-13630.

HOLMESC, STANFORDWL(2007). Concise review: stem cell antigen-1: expression, 
function, and enigma. Stem Cells 25: 1339-1347.

HONDA MJ, FONG H, IWATSUKI S, SUMITA Y, and SARIKAYA M (2008). Toothforming potential in embryonic and postnatal tooth bud cells. Med Mol Morphol 41: 183-192.

HORII T, YANAGISAWA E, KIMURAM, MORITAS, and HATADA I (2010). Epigenetic differences between embryonic stem cells generated from blastocysts developed in vitro and in vivo. Cell Reprogram 12: 551-563.

HU B, NADIRI A, BOPP-KUCHLER S, PERRIN-SCHMITT F, WANG S, and LESOT H (2005a). Dental epithelial histo-morphogenesis in the mouse: positional information versus cell history. Arch Oral Biol 50: 131-136.

HU B, NADIRI A, BOPP-KÜCHLER S, PERRIN-SCHMITT F, and LESOT H (2005b). Dental Epithelial Histomorphogenesis in vitro. J Dent Res 84: 521-525.

HU B, NADIRI A, KUCHLER-BOPP S, PERRIN-SCHMITT F, PETERS H, and LESOT $H(2006)$. Tissue engineering of tooth crown, root, and periodontium. Tissue Eng 12: 2069-2075.

IWASAKI H, KAWAMOTO A, TJWA M, HORII M, HAYASHI S, OYAMADA A, et al. (2011). PIGF repairs myocardial ischemia through mechanisms of angiogenesis, cardioprotection and recruitment of myo-angiogenic competent marrow progenitors. Plos One. 6: e24872.

JONTELLM, OKIJIT, DAHLGRENU, and BERGENHOLTZG (1998). Immune defense mechanisms of the dental pulp. Crit Rev Oral Biol Med. 9: 179-200.

KARAÖZ E, DOĞAN BN, AKSOY A, GACAR G, AKYÜZ S, AYHAN S, et al. (2010). Isolation and in vitro characterisation of dental pulp stem cells from natal teeth. Histochem Cell Biol 133: 95-112.

KELLER L, KUCHLER-BOPP S, MENDOZA SA, POLIARD A, and LESOT H (2011). Tooth engineering: searching for dental mesenchymal cells sources. Front Physiol 2: 7.

KUCHLER-BOPP, S., KELLER, L., POLIARD, A., and LESOT, H. (2011).Tooth Organ Engineering: Biological Constraints Specifying Experimental Approaches. In In Tech (Ed. D. Eberli). Tissue Engineering for tissue and organ regeneration, pp.317-346.

LEE SB, SEO D, CHOI D, PARK K-Y, HOLCZBAUER A, MARQUARDT JU, et al. (2012). Contribution of hepatic lineage stage-specific donor memory to the differential potential of induced mouse pluripotent stem cells. Stem Cells 30: 997-1007.

LESOT H, BROOK AH (2009). Epithelial histogenesis during tooth development. Arch Oral Biol 54 Suppl 1: S25-33.

LU H, SEARLE K, LIU Y, and PARKER T (2012). The Effect of Dimensionality on Growth and Differentiation of Neural Progenitors from Different Regions of Fetal Rat Brain in vitro: 3-Dimensional Spheroid versus 2-Dimensional Monolayer Culture. Cells Tissues Organs 196: 48-55.

MAGLOIRE H, MAURINJC, COUBLE ML, SHIBUKAWAY, TSUMURAM, THIVICHONPRINCE B, et al. (2010). Topical review. Dental pain and odontoblasts: facts and hypotheses. J Orofac Pain 24: 335-349.

MOE K, KETTUNEN P, KVINNSLAND IH, and LUUKKO K (2008). Development of the pioneer sympathetic innervation into the dental pulp of the mouse mandibular first molar. Arch Oral Biol 53: 865-873.

MOKRY J, SOUKUP T, MICUDA S, KARBANOVA J, VISEK B, BRCAKOVA E, et al. (2010). Telomere attrition occurs during ex vivo expansion of human dental pulp stem cells. J Biomed Biotechnol DOI: 10.1155/2010/673513
NAIT LECHGUER A, KUCHLER-BOPP S, HU B, HAÏKEL Y, and H LESOT (2008). Vascularization of engineered teeth. J Dent Res 87: 1138-1143.

NAIT LECHGUER A, COUBLE ML, LABERT N, KUCHLER-BOPP S, KELLER L, MAGLOIRE $\mathrm{H}$, et al. (2011). Cell differentiation and matrix organization in engineered teeth. J Dent Res 90: 583-589.

NAKASHIMA M, IOHARA K, and SUGIYAMA M (2009). Human dental pulp stem cells with highly angiogenic and neurogenic potential for possible use in pulp regeneration. Cytokine Growth Factor Rev 20: 435-440.

OHAZAMAA, MODINO SAC, MILETICH I, and SHARPE PT (2004). Stem-cell-based tissue engineering of murine teeth. J Dent Res 83: 518-522.

OKIJI, T. (2012). Pulp as a connective tissue. In Seltzer and Bender's dental pulp. (Eds. K. M. Hargreaves, H. E. Goodis), Quintessence, Chicago, pp. 67-89.

OKIJI T, JONTELL M, BELICHENKO P, BERGENHOLTZ G, and DAHLSTRÖM A (1997). Perivascular dendritic cells of the human dental pulp. Acta Physiol Scand 159: 163-169.

OSHIMA M, MIZUNO M, IMAMURAA, OGAWA M, YASUKAWA M, YAMAZAKI H, et al. (2011). Functional tooth regeneration using a bioengineered tooth unit as a mature organ replacement regenerative therapy. Plos One 6: e21531

OTSUK, KISHIGAMIR, OIKAWA-SASAKIA, FUKUMOTO S, YAMADAA, FUJIWARA $\mathrm{N}$, et al. (2012). Differentiation of Induced Pluripotent Stem Cells Into Dental Mesenchymal Cells. Stem Cells Dev. 21: 1156-1164.

PATELM, SMITHAJ, SLOANAJ, SMITH G, and COOPERPR (2009). Phenotype and behaviour of dental pulp cells during expansion culture. Arch Oral Bio/54: 898-908.

PEI M, LI JT, SHOUKRY M, and ZHANG Y (2011). A review of decellularized stem cell matrix: a novel cell expansion system for cartilage tissue engineering. Eur Cell Mater 22: 333-343.

ROTHOVÁ M, FENG J, SHARPE PT, PETERKOVÁ R, and TUCKER AS (2011) Contribution of mesoderm to the developing dental papilla. Int J Dev Bio/55:59-64.

SHI S, GRONTHOS S (2003). Perivascular niche of postnatal mesenchymal stem cells in human bone marrow and dental pulp. J Bone Miner Res 18: 696-704.

SMITH AJ, LESOT H (2001). Induction and regulation of crown dentinogenesis: embryonic events as a template for dental tissue repair? Crit Rev Oral Biol Med 12: 425-437.

TAKEDACHI M, OOHARA H, SMITH BJ, IYAMA M, KOBASHI M, MAEDA K, et al. (2012). CD73-generated adenosine promotes osteoblast differentiation. J Cell Physiol 227: 2622-2631.

VOLPONI AA, PANG Y, and SHARPE PT (2010). Stem cell-based biological tooth repair and regeneration. Trends Cell Biol 20: 715-722.

WANG X, HU Q, NAKAMURA Y, LEE J, ZHANG G, FROM AHL, et al. (2006). The role of the sca-1+/CD31- cardiac progenitor cell population in postinfarction left ventricular remodeling. Stem Cells 24: 1779-1788.

YU J, HE H, TANG C, ZHANG G, LI Y, WANG R, et al. (2010). Differentiation potential of STRO-1+ dental pulp stem cells changes during cell passaging. BmC Cell Biol 11: 32.

ZHANG J, KAWASHIMAN, SUDA H, NAKANO Y, TAKANOY, and AZUMAM (2006). The existence of $C D 11 \mathrm{C}+$ sentinel and $\mathrm{F} 4 / 80+$ interstitial dendritic cells in dental pulp and their dynamics and functional properties. Int Immunol 18: 1375-1384. 


\section{Further Related Reading, published previously in the Int. J. Dev. Biol.}

Contribution of mesoderm to the developing dental papilla

Michaela Rothová, Jifan Feng, Paul T. Sharpe, Renata Peterková and Abigail S. Tucker

Int. J. Dev. Biol. (2011) 55: 59-64

Developmental expression of Smad1-7 suggests critical function of TGF-beta/BMP signaling in regulating epithelial-mesenchymal interaction during tooth morphogenesis.

Xun Xu, Lesley Jeong, Jun Han, Yoshihiro Ito, Pablo Bringas and Yang Chai

Int. J. Dev. Biol. (2003) 47: 31-39

Cell-matrix interactions and cell-cell junctions during epithelial histo-morphogenesis in the developing mouse incisor.

S Kieffer-Combeau, J M Meyer and H Lesot

Int. J. Dev. Biol. (2001) 45: 733-742

Mouse odontogenesis in vitro: the cap-stage mesenchyme controls individual molar crown morphogenesis.

R Schmitt, H Lesot, J L Vonesch and J V Ruch

Int. J. Dev. Biol. (1999) 43: 255-260

Initial features of the inner dental epithelium histo-morphogenesis in the first lower molar in mouse.

H Lesot, R Peterková, R Schmitt, J M Meyer, L Viriot, J L Vonesch, B Senger, M Peterka and J V Ruch

Int. J. Dev. Biol. (1999) 43: 245-254

Timing of the expression of enamel gene products during mouse tooth development. M Zeichner-David, H Vo, H Tan, T Diekwisch, B Berman, F Thiemann, M D Alcocer, P Hsu, T Wang, J Eyna, J Caton, H C Slavkin and M MacDougall

Int. J. Dev. Biol. (1997) 41:27-38

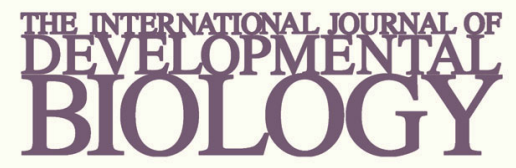

Volume 54 Nos. $6 / 7$
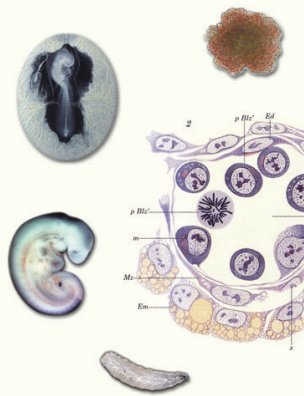

(2)

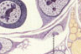

$$
\text { Special Issue }
$$
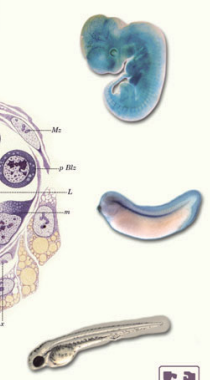

Developmental Hematopoiesis
5 yr ISI Impact Factor $(2011)=2.959$
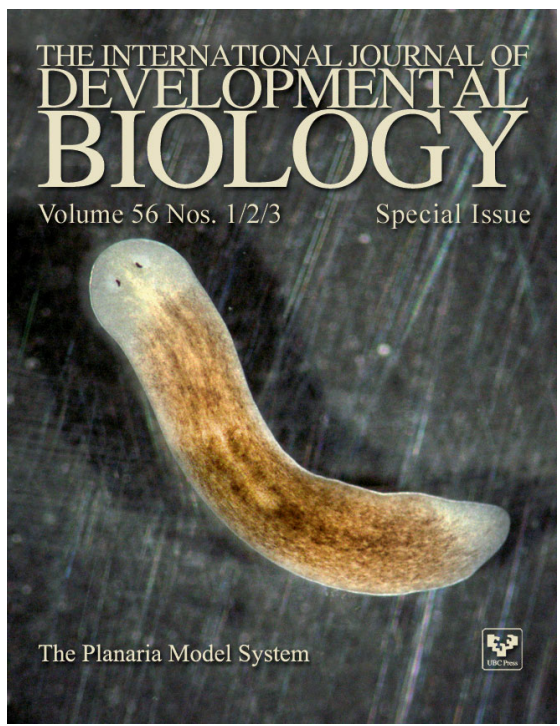
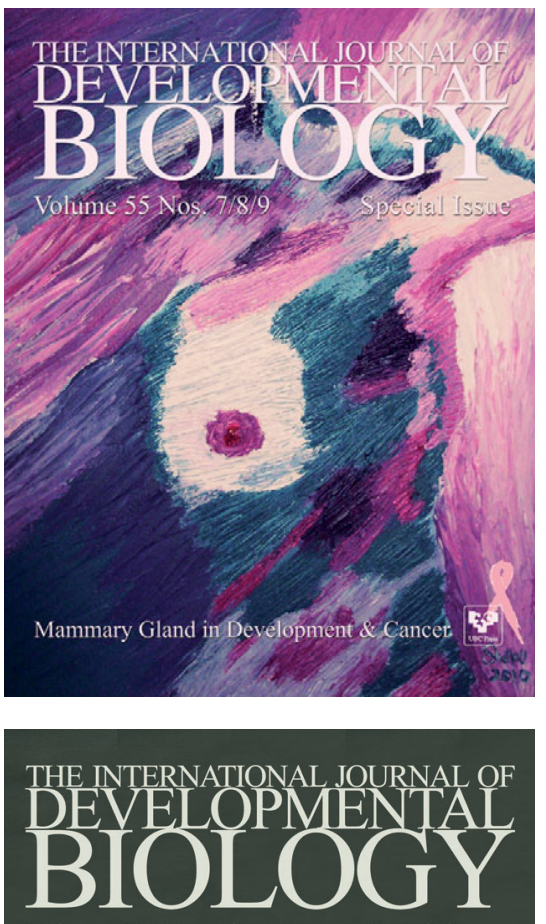

Volume 55 Nos. $4 / 5$

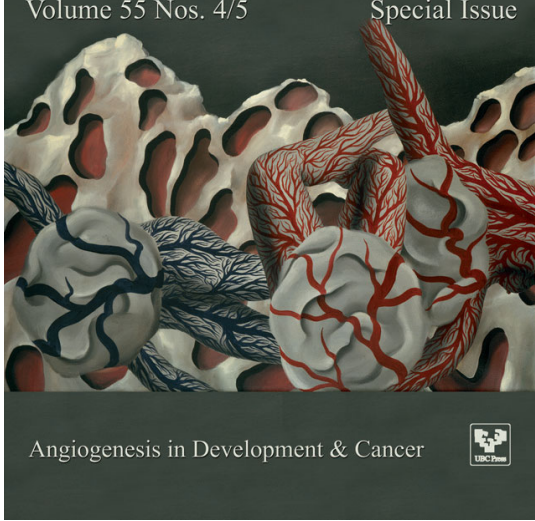

